\title{
Nutritional and Epidemiological Requirements for Growth and Sporulation of Fusarium oxysporum f. sp. lentis caused Lentil Wilt
}

\author{
Meenu Kumari Meena*, C. B. Meena, D. L. Yadav, H. P. Meghwal, \\ Sandhya and Karan Singh \\ Department of Plant Pathology, College of Agriculture, Ummedanj (Kota), India \\ *Corresponding author
}

\section{A B S T R A C T}

\begin{tabular}{l} 
K e y w o r d s \\
Lentil, Fusarium \\
oxysporum f. sp. \\
lentis, Culture \\
media, pH, \\
Temperature, \\
Colony Growth and \\
sporulation, lentil \\
wilt \\
\hline $\begin{array}{l}\text { Article Info } \\
\text { Accepted: } \\
\text { 25 June } 2020 \\
\text { Available Online: } \\
\text { 10 July } 2020\end{array}$ \\
\hline
\end{tabular}

\section{Keywords}

Lentil, Fusarium media, $\mathrm{pH}$, Temperature, Colony Growth and sporulation, lentil Article Info

Accepted: Available Online:

\section{Introduction}

Lentil (Lens culinaris M.) is an edible pulse and belongs to the family Leguminosae. It is a bushy annual plant of the legume family, grown for its lens shaped seeds. Grain of lentil contains $26 \%$ protein and $1 \%$ fat. It is also rich in vitamins (thiamin and folate) and minerals $(\mathrm{Ca}, \mathrm{P}, \mathrm{Fe}$ and $\mathrm{Zn})$. It is a valuable crop for maintaining soil fertility having a capacity of Nitrogen fixing (Joshi, 1998). Lentil is largely consumed as dal and also use as food and fodder, the leaves, stems \& threshed pods of lentil are important for feeding sheep and goats. In India, lentil is mostly grown in northern plains, central and eastern parts of India. The total area under lentil in India was 14.94 Lakh ha with a total production of 15.06 Lakh tonnes at 1008 $\mathrm{kg} / \mathrm{ha}$ productivity. In Rajasthan, lentil is grown in Bundi, Kota, Pratapgarh, Bhilwara, Jhalawar and Bhartpur districts covering the total area of 0.31 Lakh hectare, producing 0.43 Lakh tonnes with productivity of 1387 
$\mathrm{kg} / \mathrm{ha}$, during 2017-18 (Anonymous,2019). Biotic stresses such as fusarium wilt (Fusarium oxysporum f. sp. lentis), ascochyta blight (Ascochyta lentis), stemphylium blight (Stemphylium botryosum), anthracnose (Colletotrichum truncatum), root rot (Rhizoctonia solani), rust (Uromyces viciaefabae), white mold (Sclerotinia sclerotiorum) and collar rot (Sclerotiun rolfsii), (Kumar et al., 2013) cause severe yield loss. Among diseases, Fusarium wilt caused by Fusarium oxysporum f. sp. lentis is one of the major diseases affecting lentil yield all over the world (Bayaa et al., 1998; Khare 1981). Lentil wilt is a serious disease caused by Fusarium oxysporum f. sp. lentis (Fol) and plays major role in reducing lentil yield in India and world (Hamdi and Hassanein, 1996). Fusarium wilt causes yield losses up to $50 \%$ in India.Present experiment deals with study of mycelium growth and sporulation under in-vitro condition at different culture media, various temperatures and $\mathrm{pH}$ level. To carry out the research, eight distinctive culture media viz.,Potato Dextrose Agar (Natural), V8 Juice Agar (Hi-Media), C-Zepak's Agar (Hi-Media), Potato Dextrose Agar (HiMedia), Oat Meal Agar (Hi-Media), Corn Meal Agar, Lentil Leaf Extract Agar and Lentil Root Extract Agar were used to evaluate for the mycelium growth and sporulation of pathogen. Later suitable temperature and $\mathrm{pH}$ were also analyzed for the pathogen growth and sporulation by incubating at different $\mathrm{pH}$ level viz., 5.0, 6.0, 7.0, 8.0 and 8.5 and temperatures regimes viz., $10^{\circ} \mathrm{C}, 15^{\circ} \mathrm{C}, 20^{\circ} \mathrm{C}, 25^{\circ} \mathrm{C}, 30^{\circ} \mathrm{C}$ and $35^{\circ} \mathrm{C}$.

\section{Materials and Methods}

\section{Collection}

Infected plants which showing typical wilting symptoms were collected during the month of January-February, 2019 from the lentil fields ofAICRP on MULLaRP at ARS, Ummedganj (Kota). Samples were brought in the
Department of Plant Pathology, College of Agriculture, Ummedganj, Kota for isolation and further studies.

\section{Isolation of fungus}

For isolation of the pathogen standard tissue isolation technique followed (Aneja, 2018). The diseased lentil plant showing the wilt symptoms were washed thoroughly with tap water, small pieces $\left(3 \mathrm{~mm}^{2}\right)$ from infected roots were cut with the help of sterilized blade. Then these pieces were surface sterilized with $0.1 \% \mathrm{HgCl}_{2}$ solution for one minute. Such pieces were washed thoroughly in sterile distilled water subsequently three times to remove traces of mercuric chloride solution, and then aseptically transferred to sterilized potato dextrose agar (PDA) plates. Petri plate were incubated at $25 \pm 1^{\circ} \mathrm{C}$ for three days for growth of the fungus. Later, the bit of fungal growth was transferred to PDA petri plates. The pure culture of the fungus was obtained by further growing the culture and following hyphal tip culture under aseptic conditions.

\section{Identification of fungus}

The pathogen Fusarium oxysporum f. sp. lentis forms cottony white colonies on petri plates containing PDA. The colonies appeared as pure white mycelial growth were identified by observing the colony against light with the naked eyes and later confirmed sporulation with the help of microscope. On the basis of these characters the pathogen was identified as Fusarium oxysporum f. sp. lentis. Further, identification of pathogen was confirmed and it is identified by Indian Type Culture Collection, Division of Plant Pathology, IARI, New Delhi as Fusarium oxysporum (I. D. No. 11,029.19 \& Date- 25/03/2019).

\section{Preparation of Culture Media}

Different culture media viz.,Potato Dextrose 
Agar (Natural), V-8 Juice Agar (Hi-Media), C-Zepak's Agar (Hi-Media), Potato Dextrose Agar (Hi-Media), Oat Meal Agar (Hi-Media), Corn Meal Agar, Lentil Leaf Extract Agar and Lentil Root Extract Agar were prepared to carry out the study.

All the media were sterilized at $121.6^{\circ} \mathrm{C}$ temperature and $1.05 \mathrm{~kg} / \mathrm{cm}^{2}$ (15 lbs $\mathrm{psi}$ ) pressure for $15 \mathrm{~min}$. To carry out study, cool $\&$ molten media near about $20-25 \mathrm{ml}$ of each of the medium was poured in each prior Sterilized petriplates. After solidification of media such petriplates were inoculated with 6 $\mathrm{mm}$ disc cut from the periphery of actively growing fungal culture grown in petri plates by using sterilized cork borer and incubated at $25 \pm 1{ }^{\circ} \mathrm{C}$. Each treatment was replicated thrice. Radial growth of colony was recorded by measuring colony diameter in millimetre at $7^{\text {th }}$ days after inoculation and sporulation density per microscopic field at $15^{\text {th }}$ days after inoculation. The data obtained were analysed statistically.

\section{Effect of various temperature on growth and sporulation of Fusarium oxysporum f. sp. lentis}

Twenty $\mathrm{ml}$ of sterilized potato dextrose agar (PDA) was poured in sterilized $90 \mathrm{~mm}$ diameter petriplates. Each treatment was repeated four times. The petri plates were inoculated aseptically after solidification of medium by placing $6 \mathrm{~mm}$ diameter mycelial disc in the centre, cut aseptically with the help of cork-borer from 5 days old pure culture of F. oxysporum f. sp. lentis.

These petri plates were incubated at various temperatures range viz., 10, 15, 20, 25, 30, and $35 \pm 1^{\circ} \mathrm{C}$ in B.O.D. incubator. Observations on radial growth and sporulation of fungus were recorded. After $7^{\text {th }}$ days of incubation, observations on radial growth and sporulation density per microscopic field at $15^{\text {th }}$ days after inoculation. The data obtained were analysed statistically.

Effect of various $\mathrm{pH}$ on growth and sporulation of Fusarium oxysporum f. sp. Lentis

The set of media having different $\mathrm{pH}$ viz., 5.0, 6.0, 7.0, 8.0 and 8.5 were prepared and $\mathrm{pH}$ was adjusted by adding appropriate amount $\mathrm{N} / 10 \mathrm{HCl}$ or $\mathrm{N} / 10 \mathrm{NaOH}$ solutions in PDA medium with $\mathrm{pH}$ meter. After adjusting $\mathrm{pH}$, the medium was sterilized in an autoclave. After sterilizing media, before cooling it at $45^{\circ} \mathrm{C}$ temperature, $20-25 \mathrm{ml}$ of media was poured separately in sterilized petri plates aseptically. After solidifying media, $6 \mathrm{~mm}$ disc of fungus was cut aseptically with the help of sterilized cork borer and placed in petri-plates and were incubated at $25 \pm 1^{\circ} \mathrm{C}$ temperature in an incubator. For each $\mathrm{pH}$ value, four replications were maintained.

Observations on radial growth and sporulation of fungus were recorded. After $7^{\text {th }}$ days of incubation, observations on radial growth and sporulation density per microscopic field at $15^{\text {th }}$ days after inoculation. The data obtained were analysed statistically.

\section{Estimation of sporulation}

For estimating the sporulation, after $15^{\text {th }}$ days after incubation period $5 \mathrm{~mm}$ disc was cut and suspended in $10 \mathrm{ml}$ of distilled water and shaken well to harvest spores. Number of spores were counted with the help of Haemocytometer.

The results have been expressed as excellent, good, fair, poor, and no sporulation on the basis of following scale are suggested by (Singh, 2015). 
Details of expression of sporulation

\begin{tabular}{|c|c|c|}
\hline Sporulation & Represented as & No. of spores/ microscopic field \\
\hline Excellent & ++++ & $61 \&$ above \\
\hline Good & +++ & $41-60$ \\
\hline Fair & ++ & $21-40$ \\
\hline poor & + & Less than 20 \\
\hline No & - & Nil \\
\hline
\end{tabular}

\section{Results and Discussion}

Effect of different solid culture media on mycelial growth and sporulation of Fusarium oxysporum f. sp. Lentis

The pathogen was inoculated on different media and observed that maximum colony diameter $(90.00 \mathrm{~mm})$ recorded on oat meal agar (Hi-media) medium, which was statistically at par with potato dextrose agar (Hi-media) yielded $88.57 \mathrm{~mm}$ colony diameter but significantly superior as compared to potato dextrose agar (Natural), V-8 juice agar (Hi-Media), lentil Root extract agar, Czepak's agar (Hi-Media) and corn meal agar were respectively, 86.67, 84.00, 78.40, 69.40 and $37.57 \mathrm{~mm}$. Potato dextrose agar (Hi- media) was at par when compared to potato dextrose agar (Natural). Least colony diameter $(19.73 \mathrm{~mm})$ of the test fungus was recorded on lentil leaf extract agar. Similarly, effect on sporulation test fungus sporulated in all medium tried except lentil leaf extract agar and corn meal agar, which not supported for sporulation and also observed scanty mycelial growth. Fungus sporulated excellently in oat meal agar (Hi-media), potato dextrose agar (Hi-media) and potato dextrose agar (Natural). While good sporulation was recorded in V-8 juice agar (Hi-Media) medium. Fair sporulation was observed in lentil root extract agar and C-zepak's agar (Hi-Media) medium according to sporulation scale.

Table.1 In-vitro effect of different solid culture medium on mycelial growth and sporulation of Fusarium oxysporum f. sp. Lentis

\begin{tabular}{|l|c|c|}
\hline \multicolumn{1}{|c|}{ Medium Name } & $\begin{array}{l}\text { Colony diameter in } \mathbf{~ m m ~ ( 1 6 8} \\
\text { HAI) }\end{array}$ & Sporulation** \\
\hline $\mathbf{T}_{\mathbf{1}}=$ Potato Dextrose Agar (Natural) & 86.67 & ++++ \\
\hline $\mathbf{T}_{\mathbf{2}}=\mathbf{\text { V-8 Juice Agar (Hi-Media) }}$ & 84.00 & +++ \\
\hline $\mathbf{T}_{3}=$ C-Zepak's Agar (Hi-Media) & 69.40 & ++ \\
\hline $\begin{array}{l}\mathbf{T}_{4}=\text { Potato Dextrose Agar (Hi- } \\
\text { Media) }\end{array}$ & 88.57 & +++ \\
\hline $\mathbf{T}_{5}=$ Oat Meal Agar (Hi-Media) & 90.00 & ++++ \\
\hline $\mathbf{T}_{6}=$ Corn Meal Agar & 37.57 & - \\
\hline $\mathbf{T}_{7}=$ Lentil Leaf Extract Agar & 19.73 & - \\
\hline $\mathbf{T}_{\mathbf{8}}=$ Lentil Root Extract Agar & 78.40 & ++ \\
\hline S Em. $\mathbf{= 0 . 5 0}$ & C.D. at $\mathbf{0 . 0 5 \%}=\mathbf{1 . 5 0}$ & \\
\hline
\end{tabular}

*Mean of three replications; HAI $=$ Hours after inoculation

$* *$ Categories of sporulation: Excellent $(++++)=61 \&$ above, Good $(+++)=41-60$, Fair $(++)=21-40$, Poor $(+)=$ Less than 20, No $(-)=$ Nil 
Table.2 In-vitro effect of different temperature level on growth and sporulation of Fusarium oxysporum f. sp. Lentis

\begin{tabular}{|r|c|c|}
\hline Temperature $\left({ }^{\circ} \mathbf{C}\right)$ & Colony diameter in mm (168 HAI) & Sporulation $^{* *}$ \\
\hline $\mathbf{T}_{\mathbf{1}}=\mathbf{1 0}{ }^{\circ} \mathrm{C}$ & 21.00 & + \\
\hline $\mathbf{T}_{\mathbf{2}}=\mathbf{1 5}^{\circ} \mathrm{C}$ & 38.50 & + \\
\hline $\mathbf{T}_{\mathbf{3}}=\mathbf{2 0 ^ { \circ } \mathrm { C }}$ & 66.50 & +++ \\
\hline $\mathbf{T}_{\mathbf{4}}=\mathbf{2 5 ^ { \circ } \mathrm { C }}$ & 87.00 & ++++ \\
\hline $\mathbf{T}_{\mathbf{5}}=\mathbf{3 0}{ }^{\circ} \mathrm{C}$ & 90.00 & ++++ \\
\hline $\mathbf{T}_{\mathbf{6}}=\mathbf{3 5}{ }^{\circ} \mathrm{C}$ & 58.50 & ++ \\
\hline $\mathbf{S ~ E m} . \pm=\mathbf{0 . 5 3}$ & C.D. at $\mathbf{0 . 0 5 \%}=\mathbf{1 . 5 9}$ & \\
\hline
\end{tabular}

*Mean of four replications; HAI= Hours after inoculation

**Categories of sporulation: Excellent $(++++)=61 \&$ above, Good $(+++)=41-60$, Fair $(++)=21-40$, Poor $(+)=$ Less than 20, No $(-)=$ Nil

Table.3 In-vitro effect of different $\mathrm{pH}$ level on growth and sporulation of Fusarium oxysporum f. sp. lentis

\begin{tabular}{|c|c|c|}
\hline pH level & $\begin{array}{l}\text { Colony diameter in mm (168 HAI) } \\
*\end{array}$ & Sporulation** \\
\hline $\mathbf{T}_{1}=\mathbf{5 . 0}$ & 86.50 & +++ \\
\hline$T_{2}=6.0$ & 90.00 & ++++ \\
\hline $\mathbf{T}_{3}=\mathbf{7 . 0}$ & 82.50 & +++ \\
\hline $\mathbf{T}_{4}=8.0$ & 76.50 & ++ \\
\hline $\mathbf{T}_{5}=8.5$ & 57.50 & + \\
\hline \multicolumn{3}{|c|}{ C.D. at $0.05 \%=1.58$} \\
\hline
\end{tabular}

*Mean of four replications; HAI=hours after inoculation

**Categories of sporulation: Excellent $(++++)=61 \&$ above, Good $(+++)=41-60$, Fair $(++)=21-40$, Poor $(+)=$ Less than 20, No (-) $=$ Nil

Plate.4.2 In-vitro effect of different solid culture medium on mycelial growth and sporulation of Fusarium oxysporum f. sp. Lentis

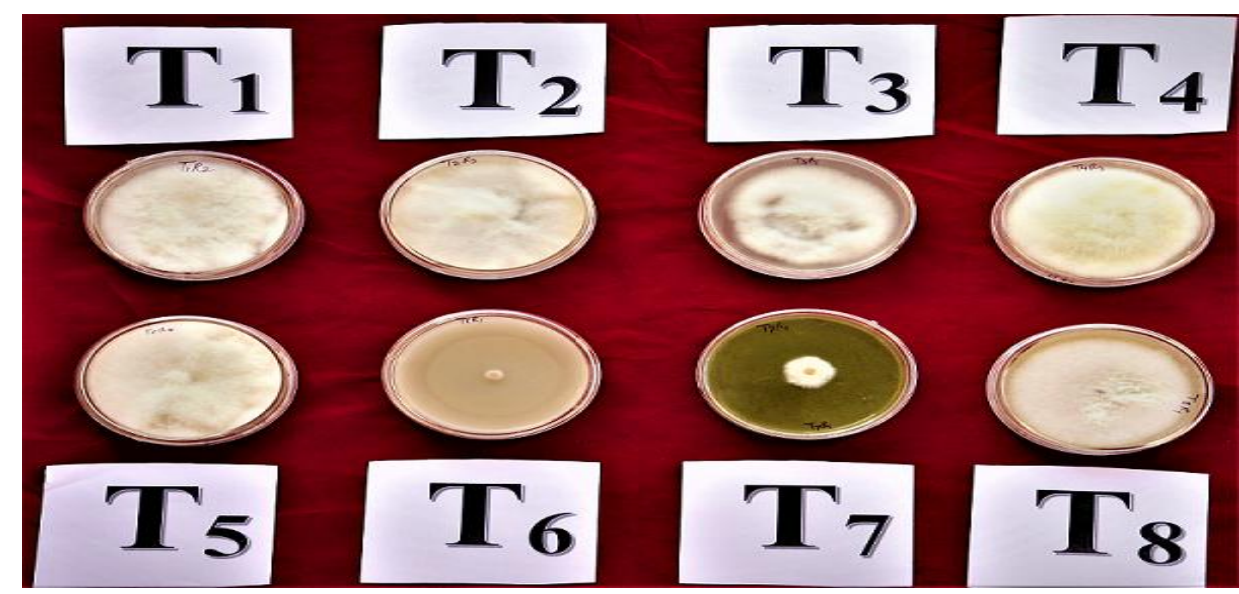

$\mathrm{T}_{1}=$ Potato Dextrose Agar (Natural), $\mathrm{T}_{2}=\mathrm{V}-8$ Juice Agar (Hi-Media), $\mathrm{T}_{3}=$ C-Zepak's Agar (HiMedia), $\mathrm{T}_{4}=$ Potato Dextrose Agar (Hi-Media), $\mathrm{T}_{5}=$ Oat Meal Agar (Hi-Media), $\mathrm{T}_{6}=$ Corn Meal Agar, $\mathrm{T}_{7}=$ Lentil Leaf Extract Agar, $\mathrm{T}_{8}=$ Lentil Root Extract Agar 
Plate.3 In-vitro effect of different temperature level on growth and sporulation of Fusarium oxysporum f. sp. Lentis

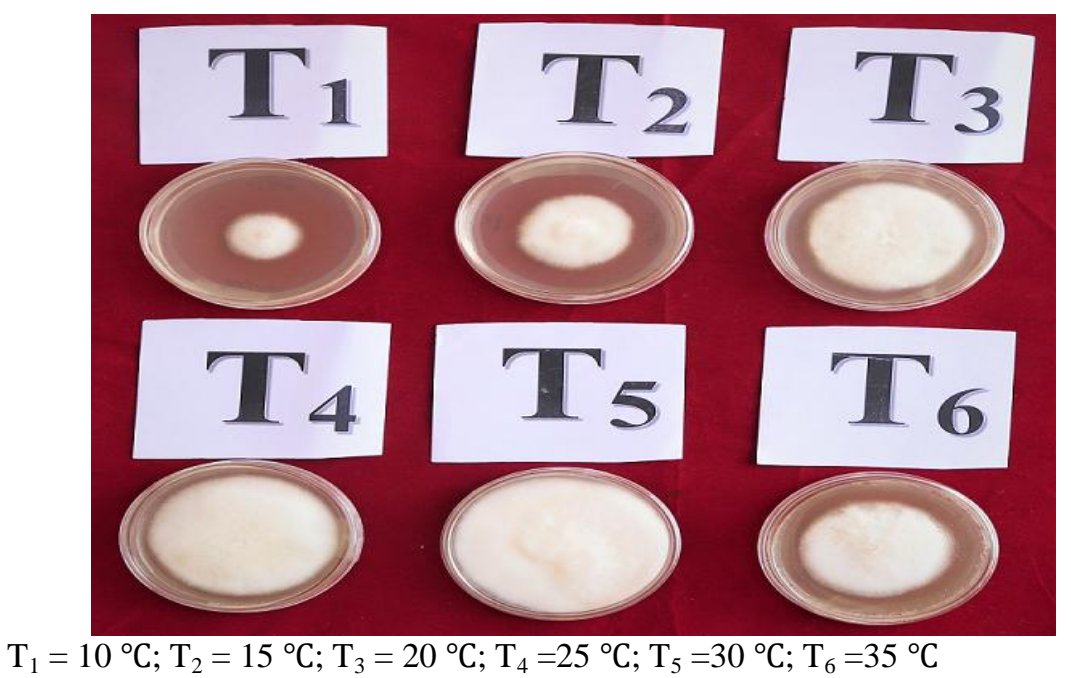

Plate.4 In-vitro effect of different $\mathrm{pH}$ level on growth and sporulation of Fusarium oxysporum f. sp. lentis

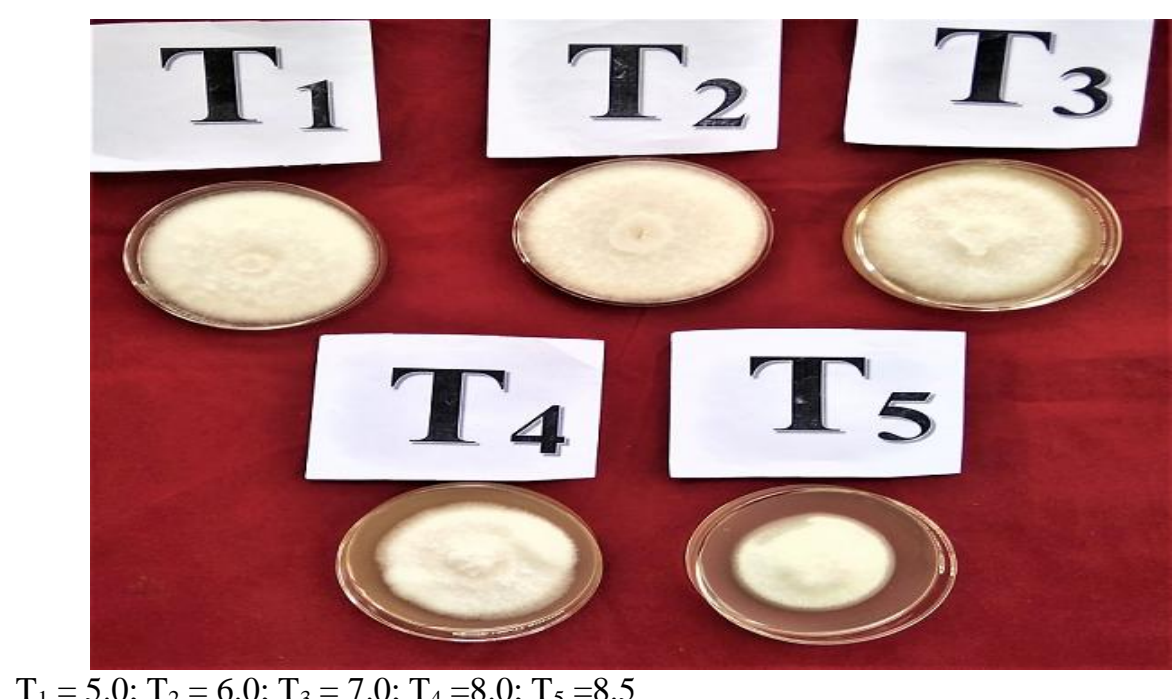

Similar findings were reported by several others workers Khare et al., (1975) reported maximum growth and sporulation of Fusarium oxysporum f. sp. lentis on PDA, followed by lentil extract and Richard's agar medium. Khan et al., (2011) also reported PDA an excellent medium for growth and sporulation, followed by Richard's agar medium. Singh et al., (2016) studied effect of different solid media and liquid media on radial growth and sporulation of Fusarium oxysporum f. sp. lentis. Potato dextrose agar and Richard's agar were the best medium for radial growth and sporulation of Fusarium oxysporum f. sp. lentis. Kumar et al., (2019) found that fungus grew the best on PDA and Richard's agar media among seven culture media were tested. Poorvasandhya et al., (2020) reported that PDA and Czapek's dox agar media provided maximum mycelia 
growth, sporulation, fresh weight and dry mycelial weight of Fusarium oxysporum f. sp. udum.

In-vitro effect of different temperature level on growth and sporulation of Fusarium oxysporum f. sp. Lentis

The temperature ranges for growth vary for all microorganisms as well as for host pathogen interactions. After $168 \mathrm{hrs}$ of incubation, significantly higher mycelial growth $(90.00 \mathrm{~mm})$ was observed at $30^{\circ} \mathrm{C}$, as compared to $25^{\circ} \mathrm{C}$ produced $87.00 \mathrm{~mm}$ colony diameter. A sudden fall in mycelial growth of Fusarium oxysporum f. sp. lentis was observed in both increasing and decreasing of temperature level, at $20^{\circ} \mathrm{C}, 35^{\circ} \mathrm{C} 15^{\circ} \mathrm{C}$ and $10^{\circ} \mathrm{C}$ significantly decrease mycelial growth of the fungus and yielded colony diameter $66.50 \mathrm{~mm}, 58.50 \mathrm{~mm}, 38.50 \mathrm{~mm}$ and $21.00 \mathrm{~mm}$, respectively. On other hand Excellent sporulation density was observed under microscopic field at temperature $30^{\circ} \mathrm{C}$ and $25^{\circ} \mathrm{C}$, respectively. Good sporulation was recorded at $20^{\circ} \mathrm{C}$ and Fair sporulation occurred at $35^{\circ} \mathrm{C}$ temperature. While, poor sporulation was observed at temperature $15^{\circ} \mathrm{C}$ and $10^{\circ} \mathrm{C}$, respectively.

In-vitro effect of different pH level on growth and sporulation of Fusarium oxysporum f. sp. Lentis

Growth of the test fungus was obtained at all $\mathrm{pH}$ levels tested but it was significantly higher at $\mathrm{pH} 6.0(90.00 \mathrm{~mm})$ after $168 \mathrm{hrs}$. of incubation when compared with $\mathrm{pH} 5.0$ $(86.50 \mathrm{~mm})$ and $\mathrm{pH} 7.0(82.50 \mathrm{~mm})$ found favourable $\mathrm{pH}$ level for mycelial growth. Growth of pathogen showed decline in both condition increasing or decreasing the $\mathrm{pH}$ level from the $\mathrm{pH}$ 6.0. Minimum growth was observed at $\mathrm{pH}$ level 8.5 yielded $57.50 \mathrm{~mm}$ colony diameter. Effect on sporulation also observed and found that, Excellent sporulation was observed at $\mathrm{pH}$ 6.0. Good sporulation was recorded at $\mathrm{pH} 5.0$ and 7.0, respectively. $\mathrm{pH} 8.0$ supported Fair sporulation while, poor sporulation was observed at $\mathrm{pH}$ level 8.5.

Similarly, findings correlated with Chaudhary et al., (2018) reported that growth of F. udum was maximum at $30^{\circ} \mathrm{C}$ after seven days of inoculation, which was reduced drastically below $10^{\circ} \mathrm{C}$ and above $35^{\circ} \mathrm{C}$ and the most suitable $\mathrm{pH}$ level for growth of fungus was 6.0 and 6.5 with excellent sporulation. Khilare and Rafi (2012) found that growth of $F$. oxysporum was maximum at $30^{\circ} \mathrm{C}(24.7$ conidia/ $\mu$ l.) after seven days of inoculation, which was reduced drastically below $15^{\circ} \mathrm{C}$ and above $35^{\circ} \mathrm{C}$ and most suitable $\mathrm{pH}$ level for growth of fungus was 6.0 and 6.5 with 24.7 conidia/ $\mu$ l. Mohamed et al., (2016) concluded that, growth of $F$. oxysporum was maximum at $25^{\circ} \mathrm{C}(84 \mathrm{~mm})$ followed by $30^{\circ} \mathrm{C}(46 \mathrm{~mm})$ and also observed that, the maximum growth of the fungus was achieved at $\mathrm{pH} 7$ followed by $\mathrm{pH}$ 6. Kumar et al., (2019) reported that Growth of $F$. verticillioides was maximum at $27^{\circ} \mathrm{C}$ after seven days of inoculation, which was reduced drastically below $18^{\circ} \mathrm{C}$ and above $30^{\circ} \mathrm{C}$ and also found that, the most suitable $\mathrm{pH}$ level for growth of fungus was 6.0 and 6.5 with excellent sporulation and Kumari (2019) reported that $30^{\circ} \mathrm{C}$ temperature and $\mathrm{pH} 6.0$ was found optimum for growth and sporulation of Fusarium oxysporum f.sp lentis.

In conclusion the current experiment was conducted to revealed the suitable $\mathrm{pH}$, temperature and culture media required for the growth of pathogen. The findings and conclusions resulted from the study are here as follows; Among the eight tested culture media, Maximum colony diameter (90.00 $\mathrm{mm}$ ) recorded on oat meal agar (Hi-media) medium, which was statistically at par with potato dextrose agar (Hi-media) yielded 88.57 
mm colony diameter, Both the media support excellently sporulation by pathogen. After $168 \mathrm{hrs}$. of incubation, significantly higher mycelial growth $(90.00 \mathrm{~mm})$ was observed at $30^{\circ} \mathrm{C}$, as compared to $25^{\circ} \mathrm{C}$ produced 87.00 $\mathrm{mm}$ colony diameter. A sudden fall in mycelial growth of Fusarium oxysporum $\mathrm{f}$. sp. lentis was observed in both increasing and decreasing of temperature level. The excellent sporulation density was also observed under microscopic field at temperature $30^{\circ} \mathrm{C}$ and $25^{\circ} \mathrm{C}$. It was found that pathogen grow at all $\mathrm{pH}$ levels tested but it was significantly higher at $\mathrm{pH} \quad 6.0 \quad(90.00 \mathrm{~mm}) 168 \mathrm{hrs}$. after incubation when compared with $\mathrm{pH} 5.0$ $(86.50 \mathrm{~mm})$ and $\mathrm{pH} 7.0(82.50 \mathrm{~mm})$ found favourable $\mathrm{pH}$ level for mycelial growth, Excellent sporulation was observed at $\mathrm{pH}$ 6.0. Good sporulation was observed at $\mathrm{pH} 5.0$ and 7.0.

\section{References}

Aneja, K. R. 2018. Experiment in Microbiology, Plant Pathology, tissue Culture and Microbial Biotechnology ( $5^{\text {th }}$ edition). New Age International Publishers, New Delhi.580pp.

Anonymus. 2019. Pulses Revolution-from Food to Nutritional Security. Ministry of Agriculture \& Farmers welfare, (Dept. of Agriculture, Corporation \& Farmers Welfare), Govt. of India. 20pp.

Bayaa, B., Kumari, S. G., Akkaya, A., Erskine, W, Makkouk, K. K., Turk, Z. and Ozberk, I. 1998. Survey of major biotic stresses of lentil in South-east Anatolia. Turkey. Phytonathology Meditteraean.37: 88-95.

Chaudhary, B., Kumar, S., Sharma, R. L. and Jakhar, S. R. 2018. Effect of Different Media, $\mathrm{pH}$ and Temperature on Growth and Sporulation of Fusarium udum causing wilt of Pigeon pea. International Journal of Current Microbiology and Applied Sciences. Special Issue-6: 2005-
2011.

Hamdi, A. and Hassanein, A. M. 1996. Survey of fungal diseases of lentil in North Egypt. Lens Newsletter, 1(2): 5253.

Joshi, P. K. 1998. Performance of grain pulses in the Indo-Gangetic Plain. In J.V.D.K. Kumar Rao, C. Johansen (ed.) Residual effects of pulses in rice and wheat cropping systems of the Indo-Gangetic plain. International Crop Research Institutes for Semi-Arid Tropics (ICRISTAT). Oxford and IBH Publishing Co. Pvt. Ltd., New Delhi. ISBN 81-204-1297-4. pp 3-12.

Khan, I., H. S., Saifulla, M., Mahesh, S. B. and Pallavi, M. S. 2011. Effect of different media and environmental conditions on the growth of Fusarium oxysporum f. sp. cicericausing Fusarium wilt of chickpea. International Journal of Science and Nature. 2: 402-404.

Khare, M. N. 1981. In: Diseases of Lentils, Eds: Webb and G. Hawtin. Farnham Royal. UK; ICARDA / CAB. pp-163 172.

Khare, M. N., Agrawal, S. C. and Joshi, L. K. 1975. Studies on diseases of lentil. Proceeding XIVAnnual Workshop on Rabi Pulses, ICAR, New Delhi. pp-6.

Khilare, V.C. and Rafi, Ahmed 2012. Effect of different media, $\mathrm{pH}$ and temperature on the growth of Fusarium oxysporum $\mathrm{f}$. sp. ciceri causing chickpea wilt. International Journal of Advanced Biological Research. 2(1): 99-102.

Kumar, R., Kumar, S., Sahu, R. and Kharte, S. 2019. Effect of Different Media, $\mathrm{pH}$ and Temperature on Growth and Sporulation of Fusarium verticillioides causing crown rot of Guava. Chemical Science Review and Letters. 8(32): 352356.

Kumar, V., Garkoti, A. and Tripathi H. S. 2013. Management of vascular wilt of lentil through bio-control agents and 
organic amendments in Tarai area of Uttarakhand state. The Bioscan. 8(2):575-577.

Kumari, M. 2019. Variability, Epidemiology and Management of Lentil (Lens culinaris M.) Wilt Incited by Fusarium oxysporum f. sp. lentis. Ph. D. Thesis, RARI, Durgapura, (SKNAU, Jobner) Jaipur.

Mohamed, Ekhlass Hussein, Nayla E. Haroun and Mawahib Ahmed ELsiddig AbdAlla. 2016. Control of Chickpea Wilt caused by Fusarium oxysporum f. Sp. ciceris with Botanical Extracts and Fungicides. International Journal of Current Microbiology and Applied Sciences. 5(4): 360-370.
Poorvasandhya, R., Sinha, B. and Devi, P. D. 2020. Effect of Media, Temperature and $\mathrm{pH}$ on Growth and Sporulation of Fusarium oxysporum f. sp. udum under in-vitro Condition. International Journal of Current Microbiology and Applied Sciences. 9(4): 2406-2412.

Singh, P. 2015. Studies on wilt of lentil caused by Fusarium oxysporum f. sp. lentis. M. Sc. Thesis, JNKVV, Jabalpur.

Singh, P., Kumar, S., Gupta, O. and Mishra, P. K. 2016. Effect of different media and $\mathrm{pH}$ on growth and sporulation of $F$. oxysporum f. sp. lentis causing wilt of lentil; $6^{\text {th }}$ International Conference "Plant, Pathogens and People" February 23-27, New Delhi, India.

\section{How to cite this article:}

Meenu Kumari Meena, C. B. Meena, D. L. Yadav, H. P. Meghwal, Sandhya and Karan Singh. 2020. Nutritional and Epidemiological Requirements for Growth and Sporulation of Fusarium oxysporum f. sp. lentis caused Lentil Wilt. Int.J.Curr.Microbiol.App.Sci. 9(07): 4092-4100. doi: https://doi.org/10.20546/ijcmas.2020.907.481 